\title{
GROUNDWATER QUALITY OF THE GUARANI (GAIS) AND SERRA GERAL (SGAIS) AQUIFER INTEGRATED SYSTEM IN WESTERN SANTA CATARINA, BRAZIL
}

\author{
Janete Facco \\ Universidade Federal de Santa Catarina, Departamento Geociências, Florianópolis, SC, Brasil \\ janetefacco1@gmail.com \\ Fabio Luiz Carasek \\ Universidade Comunitária da Região de Chapecó, Pós-Graduação em Ciências ambientais \\ Chapecó, SC, Brasil \\ fabio carasek@hotmail.com \\ Sival Francisco de Oliveira Junior \\ ir sival@hottmail.com \\ Manuela Gazzoni dos Passos \\ Universidade do Oeste de Santa Catarina, Campus Chapecó, Chapecó, SC, Brasil \\ biologamanu@gmail.com
}

\begin{abstract}
The objective of this work was to evaluate the groundwater quality of the Guarani/Serra Geral Integrated Aquifer System (GAIS / SGAIS) in a region located in the western part of the state of Santa Catarina. A total of 105 water wells were selected which five are exploring water from the Guarani Aquifer and 100 from the Serra Geral Aquifer. A sample of each well was submitted to microbiological (total coliforms and Escherichia coli) and physicochemical analyzes (dissolved oxygen, $\mathrm{pH}$, turbidity, electrical conductivity, alkalinity, chlorides, fluorine, sulfates, potassium, sodium, calcium, magnesium, iron, manganese, nitrate). For analyze possible contamination by BTEX hydrocarbons (benzene, toluene, ethyl benzene, xylenes) the water of 25 wells in the urban environment was analyzed in strategic points close to possible risk of risk contamination agents. In another 25 wells in the rural area the water was collected for analyze the presence of glyphosate. Some groundwater with turbidity, $\mathrm{pH}$, iron, manganese, total and thermotolerant coliforms were found in disagreement with Ministry of Health Ordinance 2914/2011. Furthermore, there was no BTEX and glyphosate contamination detected in any of the wells.
\end{abstract}

Keywords: Aquifer Guarani. Aquifer Serra Geral. Groundwater. Potability.

\section{QUALIDADE DA ÁGUA SUBTERRÂNEA DO SISTEMA INTEGRADO DE AQUÍFEROS GUARANI (SAG) E SERRA GERAL (SASG) NO OESTE DE SANTA CATARINA, BRASIL}

\begin{abstract}
RESUMO
O objetivo deste trabalho foi avaliar a qualidade da água subterrânea do Sistema Aquífero Integrado Guarani / Serra Geral (SAG / SASG) em uma região localizada no oeste do estado de Santa Catarina. Foram selecionados 105 poços de água, dos quais cinco explotam água do Aquífero Guarani e 100 do Aquífero Serra Geral. Uma amostra de cada poço foi submetida a analises microbiológicas (coliformes totais e Escherichia coli) e físico-químicas (oxigênio dissolvido, $\mathrm{pH}$, turbidez, condutividade elétrica, alcalinidade, cloretos, flúor, sulfatos, potássio, sódio, cálcio, magnésio, ferro, manganês e nitrato). Para analisar a possível contaminação por hidrocarbonetos BTEX (benzeno, tolueno, etilbenzeno, xilenos) as águas de 25 poços no ambiente urbano foram analisadas em pontos estratégicos próximos ao possível ponto de riscos dos agentes contaminadores. Em 25 poços na área rural, a água foi coletada para análise da presença de glifosato. Em algumas amostras de águas subterrâneas foram encontrados coliformes totais e termotolerantes, turbidez, $\mathrm{pH}$, ferro e manganês em desacordo com a Portaria 2914/2011 do Ministério da Saúde. Além disso, não houve contaminação por BTEX e glifosato detectadas em nenhum dos poços.
\end{abstract}

Palavras-chave: Aquífero Guarani. Aquífero Serra Geral. Água subterrânea. Potabilidade. 


\section{INTRODUCTION}

Water is a necessary resource for all forms of life, as well as for the development of the most diverse human activities. The steady increase of the use of water for supply among various economic sectors of Brazil demands investments in research to develop effective public policies through efficient management models, based on a systemic and integrated look at water resources. There is a need to invest in knowledge of aquifers and groundwater, in order to develop an integrated water resource management. Currently, in the state of Santa Catarina, well drilling control is ineffective, which may favor groundwater pollution via improperly drilled wells and / or operating in inadequate conditions, causing risks to human health and the environment. This occurs because many clandestine drillings, without the monitoring of hydrogeology professionals, especially in the west of the state Hydrographic Regions (HR) 1 and 2. According to Rebouças $(2015$, p. 33) "groundwater, a notable national patrimony, has been rapidly appropriated by the dominant economic sectors, and still unprotected legally and institutionally at federal, state and municipal levels".

Chapecó exerts a strong influence on the mesoregion of Santa Catarina, especially in commercial activities and the supply of equipment and services. This is the largest city in the West Catarinense region, both in terms of population and influence, having large industries installed on its territory (FACCO, ENGLER, 2017).

Since the exploitation of groundwater is an essential source for the maintenance of the economic sectors, whether they are primary (raising animals for slaughter and dairy cattle and irrigation), raw material processing sector (mainly meat processing industries) and third sector (sale, public supply and services).

According to several studies made in the west of Santa Catarina, where the hydrological system is located (DAL PISSOL, SOUZA-FRANCO, 2003; BAVARESCO, 2006; SANTA CATARINA, 2009; FACCO, 2011; FILIPINI, 2013; BALDISSERA, REIS, 2014; FACCO et al., 2014; FACCO, ENGLER, 2017). There is a high percentage of contamination of water resources (due to lack of sanitary sewage, animal waste, agrochemical residues and agro industries, among others).

There is a need to invest in knowledge of aquifers and groundwater for the development of an integrated water resources management become possible. Aware of the regional reality and its responsibilities, researchers from universities and institutions in Santa Catarina, Rio Grande do Sul and Paraná proposed in 2004 the formation of the Guarani / Serra Geral Network, with the objective of generating knowledge for the integrated management of surface waters and also groundwater, aiming at the use and conservation of the waters of the SGAIS/GAIS (REDE GUARANI / SERRA GERAL, 2015, p.13).

The main fact that justify this research is the lack of information about the quality of groundwater existing in all West of Santa Catarina, because this region belongs to Regions 1 and 2. According to Trindade (2016), the Basin Committees cannot make the integrated management of water resources in Santa Catarina, because the State has not implemented its State Water Resources Plan (it is ready and waiting for officialization), which will guide all management of the committees.

The objective of this work is to provide subsidies on the groundwater quality of the Guarani / Serra Geral Aquifer Integrated System (GAIS / SGAIS) in the West of Santa Catarina, Brazil.

\section{METHODOLOGY}

Water from 105 wells (100 SGAIS wells and five GAIS wells) was collected in HR 1 and 2 (Figure 1), located in southern Brazil.

Microbiological analyzes (total coliforms and fecal coliforms Escherichia coli and physicochemical parameters (dissolved oxygen (DO), hydrogen potential $(\mathrm{pH})$, turbidity, electrical conductivity (EC), alkalinity, nitrate $\left(\mathrm{NO}_{3}{ }^{-}\right)$, chlorides, sulfate $\left(\mathrm{SO}_{4}{ }^{2}\right)$, potassium $(\mathrm{K})$, sodium $(\mathrm{Na})$, calcium $(\mathrm{Ca})$, magnesium $(\mathrm{Mg})$, manganese $(\mathrm{Mn})$, iron $(\mathrm{Fe})$ were made. The analyzes were performed by the Water Laboratory Epagri, located in Chapecó, Santa Catarina. The analytical methodology adopted for the analysis of the samples is described in Standard Methods (APHA, 1998). 
Figure 1 - Location of the study in HR 1 and 2 in Santa Catarina.

\section{HYDROGRAPHIC REGIONS OF SANTA CATARINA}

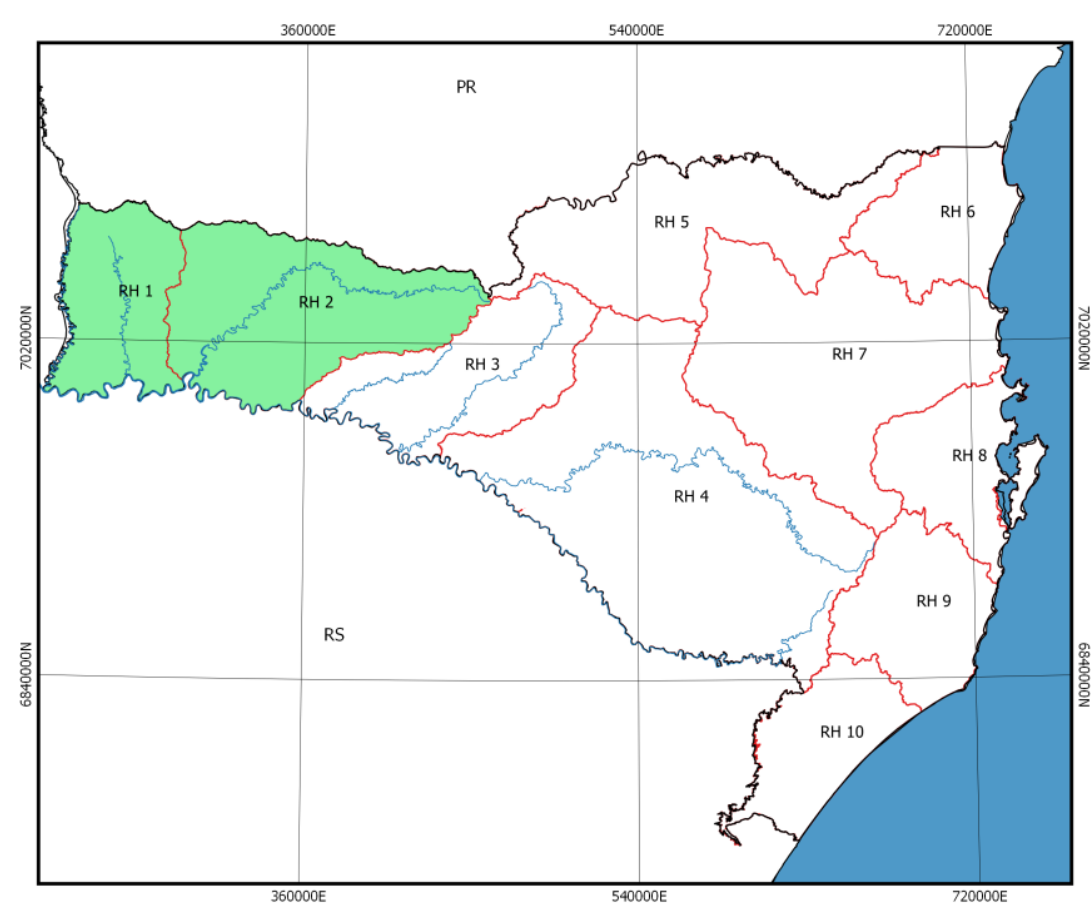

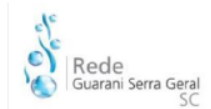
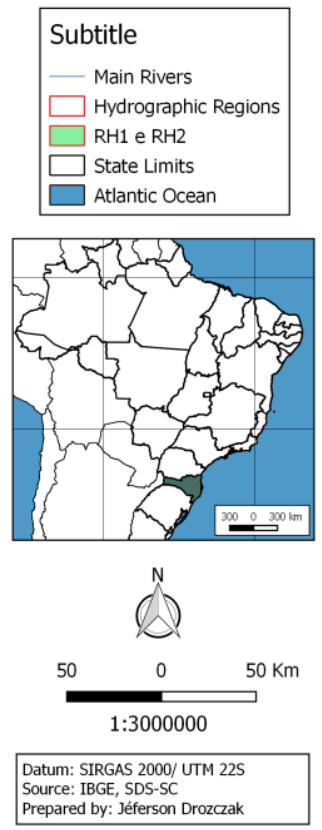

Source - IBGE, (2019) SDS-SC (2019).

For the Glyphosate analysis, the Dionex ICS-3000 Ion Chromatograph was used with lon Pac AS19 column $(2 \times 250 \mathrm{~mm})$ and AG19 pre-column. All samples for the calibration curve were filtered on $0,45 \mu \mathrm{L}$ membrane (Laboratory of the Department of Biochemistry - Biological Sciences Center - UFSC, Dr. Carlos Soares).

The analysis of the hydrocarbons (BTEX) Benzene, Toluene, Ethyl-benzene and Xylenes was made with a Gas Chromatograph with coupled masses from Agilent, model CG/MS 5977A series GC/MSD system. In addition, the equipment used the method HS GC-MS/MS with water into the Unochapecó Technology Laboratory.

For the analysis of the data it was used the QualiGraf program, which is a tool to assist in the graphic part of the most usual quality analyzes of water samples. It was developed in 2001 as a tool for internal use in the Department of Water Resources of the Cearense Foundation of Meteorology and Water Resources FUNCEME, Ceará, (FUNCEME, 2015).

\section{ANALYSIS OF THE RESULTS}

The drilling year of these wells varies from 1978 to 2017; for the 100 wells surveyed in the Serra Geral aquifer, 50 are located in a rural area and their average depth is 150.11 meters, the minimum 80 meters and the maximum 320 meters; the 50 wells of this aquifer situated in urban areas have an average depth of 162.25 meters, a minimum of 83 meters and a maximum of 408 meters.

Then, it could be conclude that the total average depth of the 100 wells of the Serra Geral aquifer analyzed was 156.47 meters, the minimum is 80 meters and the maximum 408 meters. It has been observed that, over the decades, the depth of the new perforations has increased.

The five wells analyzed from the Guarani aquifer have an average depth of 742 meters, the lowest with 580 meters and the largest with 850 meters, both located in the rural territory. 
The low oxygen $\left(\mathrm{O}^{2}\right)$ content of the two aquifers surveyed (Table 1) is justified by the chemical and physical processes of filtration and interaction with other molecules, where $\mathrm{O}^{2}$ participates in several chemical reactions, infiltrating to the saturated zone the availability of DO becomes lower due to these processes (CUSTODIO, DA SILVA Jr., 2008).

Table 1 - Dissolved Oxygen for GAIS/SGAIS Wells.

\begin{tabular}{ccc}
\hline Concentration & D.O SGAIS & D.O GAIS \\
\hline Maximum & 8,84 & 7,06 \\
\hline Minimum & 3,14 & 2,00 \\
\hline Average & 6,01 & 5,37 \\
\hline
\end{tabular}

Source - Authors, 2019.

For the physical parameter turbidity the three wells that presented alteration are in the rural zone, it was observed that the electrical conductivity for such wells was in 227.00; 353.00 and 186.90 respectively, showing a high total solids solubility in the samples, contributing to the change in turbidity. In Figure 2 it is possible to observe two of the 105 wells analyzed that are in disagreement with technical standards required in Santa Catarina.

Figure 2 - Deep tubular wells surveyed.

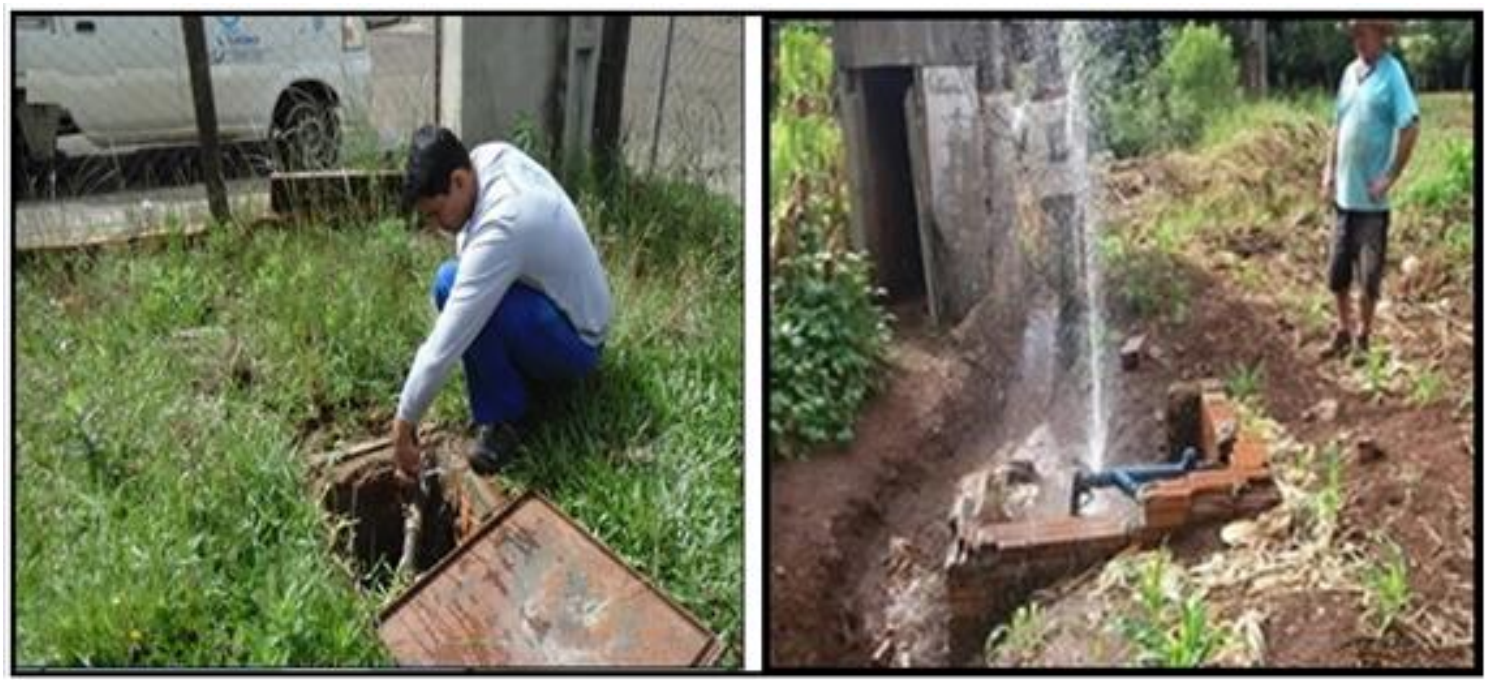

Source - Authors, 2019.

According to the statistical summary of the 105 wells, 100 of the SGAIS, (Table 1) 15 and three samples showed changes to $\mathrm{pH}$ and turbidity, respectively. For $\mathrm{pH}$ changes, 10 wells are in the rural perimeter and five in the urban perimeter. For the eight samples in which the acidic $\mathrm{pH}$ was present (below 6,00) it was noticed that $\mathrm{NO}^{-}$was present with concentrations varying from 0,66 to $6,99 \mathrm{mg} / \mathrm{L}$ with a mean for such wells of $4,21 \mathrm{mg} / \mathrm{L}$. This result shows that the probability of surface water infiltration in the wells is high, because in groundwater the natural concentration of $\mathrm{NO}_{3}$ is low, so it is a change in the natural balance levels when it is above 5,00mg/L (CETESB, 2012; SANTOS, 1997). In addition, the natural pH of the underground water resource of the fractured aquifer tends to remain between 6,00 and 8,00 (REGINATO, et al., 2012), thus $\mathrm{pH}$ below 6,00 and concentrations of $\mathrm{NO}^{-}$above $5,00 \mathrm{mg} / \mathrm{L}$ demonstrate an environmental change or disturbance in the area. In these cases, surface waters with acidic pH below 6,00 could mix with groundwater; therefore, the $\mathrm{pH}$ decreases abruptly (CARASEK, et al., 2020). All wells with $\mathrm{pH}$ below 6,00 contain contaminants and sources of $\mathrm{NO}_{3}{ }^{-}$in the environment: ( $\mathrm{P} 8=$ septic tank at 30

$\begin{array}{lllll}\text { Caminhos de Geografia } & \text { Uberlândia-MG } & \text { v. 21, n. } 77 & \text { Out/2020 } & \text { p. 59-70 }\end{array}$ 
meters, aviary at 20 meters, P27 = within experimental orchard area, weir at 7 meters, P37 $=$ tillage at 50 meters, septic tank at 15 meters, P39 = within planting area, P52 = septic tank at 10 meters, P57 = inside fuel station area, septic tank at 50 meters, P66 = urban stream; P81 = car washer at 10 meters. For the eight wells in question, only three had total coliforms with low concentrations $(1,00$ and $4,20 \mathrm{NNP} / 100 \mathrm{~mL})$, showing that the occurrence of direct infiltration of the surface water is unlikely, and that is more plausible the occurrence by saturation of the soil in the areas where the wells are inserted, collaborating directly for the $\mathrm{pH}$ change due to the possible decomposition of organic matter caused by the concentration of $\mathrm{CO}^{2}$ through the oxidation process (SILVA, et al., 2014).

For the seven wells that presented alkaline $\mathrm{pH}$ above 9,50 it was searched for a possible agent or environmental factors that directly or indirectly collaborated with such abnormality for the waters of the SGAIS, but only the electrical conductivity was positively related to the results demonstrating (C.E $=147,9$ $\mu \mathrm{S} / \mathrm{cm}$ at $339.00 \mu \mathrm{S} / \mathrm{cm}$ with mean for the seven wells of $202.14 \mu \mathrm{S} / \mathrm{cm})$. Furthermore, it was investigated the possibility of mixing waters of the SGAIS with GAIS, but it was discarded for such wells, since analytes commonly found in the GAIS were not observed in the samples of the seven wells in question.

Other analytes that were not investigated in this research are likely to generate $\mathrm{pH}$ change. Water resources of the GAIS usually present $\mathrm{pH}$ above 8,50 but can be modified due to the use and occupation of the physical environment. Inadequate disposal of domestic, industrial, mining, pesticide and fertilizer waste is the major source of pollution of water resources and can therefore lead to a change in pH (SILVA, et al., 2014).

Table 2 - Statistical summary of groundwater analyzes the study area (west of Santa Catarina).

\begin{tabular}{|c|c|c|c|c|c|c|}
\hline Parameter & Unity & Average & Minimum & Maximum & ${ }^{*}$ M.V.P. & $\begin{array}{c}\text { Number of } \\
\text { wells } \\
\text { above } \\
\text { *M.V.P }\end{array}$ \\
\hline $\mathrm{pH}$ & & 7,40 & 4,32 & 9,90 & 6,0 a 9,50 & 15 \\
\hline Turbidity & ${ }^{*} \mathrm{UT}$ & 1,17 & 0,00 & 18,00 & 5,00 & 3 \\
\hline $\begin{array}{l}\text { Electric } \\
\text { conductivity }\end{array}$ & $\mu \mathrm{S} / \mathrm{cm}$ & 202.02 & 44,60 & 747.00 & & - \\
\hline Alkalinity & $\mathrm{Mg} / \mathrm{L}$ & 80,90 & 0,00 & 305.60 & & - \\
\hline Chloride & $\mathrm{Mg} / \mathrm{L}$ & 4,41 & 0,00 & 57,23 & 250 & - \\
\hline Fluorine & $\mathrm{Mg} / \mathrm{L}$ & 0,28 & 0,00 & 0,98 & 1,50 & - \\
\hline Sulfate & $\mathrm{Mg} / \mathrm{L}$ & 12,87 & 0,00 & 115.24 & 250.00 & - \\
\hline Potassium & $\mathrm{Mg} / \mathrm{L}$ & 2,69 & 0,00 & 24,40 & & - \\
\hline Sodium & $\mathrm{Mg} / \mathrm{L}$ & 32,41 & 0,00 & 142.00 & 200.00 & - \\
\hline Calcium & $\mathrm{Mg} / \mathrm{L}$ & 17,70 & 3,50 & 60,38 & & - \\
\hline Magnesium & $\mathrm{Mg} / \mathrm{L}$ & 2,19 & 0,005 & 14,46 & ${ }^{* * *}$ C.N.S & - \\
\hline Iron & $\mathrm{Mg} / \mathrm{L}$ & 0,25 & 0,004 & 1,92 & 0,300 & 20 \\
\hline Manganese & $\mathrm{Mg} / \mathrm{L}$ & 0,11 & 0,008 & 0,86 & 0,01 & 32 \\
\hline Total coliforms & ${ }^{* *}$ P.N $/ 100 \mathrm{~mL}$ & 41,65 & 0,00 & 435.20 & Absence & 56 \\
\hline $\begin{array}{c}\text { Escherichia. } \\
\text { Coli }\end{array}$ & ${ }^{* *}$ P.N/100mL & 2,68 & 0,00 & 155.30 & Absence & 11 \\
\hline Nitrate & $\mathrm{Mg} / \mathrm{L}$ & 2,31 & 0,01 & 7,72 & 10,00 & - \\
\hline Benzene & $\mathrm{Mg} / \mathrm{L}$ & 0,00 & 0,00 & 0,00 & 5,00 & - \\
\hline Toluene & $\mathrm{Mg} / \mathrm{L}$ & 0,00 & 0,00 & 0,00 & 0,17 & - \\
\hline Ethyl- benzene & $\mathrm{Mg} / \mathrm{L}$ & 0,00 & 0,00 & 0,00 & 0,20 & - \\
\hline Xylenes & $\mathrm{Mg} / \mathrm{L}$ & 0,00 & 0,00 & 0,00 & 0,30 & - \\
\hline Glyphosate & $\mu \mathrm{g} / \mathrm{L}$ & & 0,00 & 0,00 & 500 & - \\
\hline \multicolumn{7}{|c|}{ 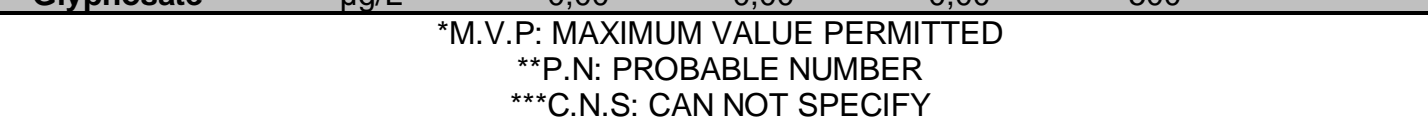 } \\
\hline
\end{tabular}

According to the main histograms and averages, the presence of $\mathrm{Mg}, \mathrm{Fe}, \mathrm{Mn}$ and $\mathrm{NO}^{-}$were observed in all 100 SGAIS samples. For metals, the response is directly associated with the Serra Geral Formation, which are important constituents of volcanic rocks. The presence in the groundwater comes from the process of physical and chemical weathering of the contact of the water with the rock 
carrying the metals and mineralizing the water resource until it reaches the natural balance point (CETESB, 2012).

Furthermore, the metals $\mathrm{Mg}, \mathrm{Fe}$ and $\mathrm{Mn}$, had a small concentration difference between rural and urban areas, corroborating the results presented by Carasek et al. (2020), which the highest concentration for the rural area was attributed to the farm factor of the groundwater in this area to be on a smaller scale precisely because of the lower number of wells in operation compared to the urban zone. According to Bittencourt et al (2003), this factor directly influences the residence time of groundwater where, for the rural zone, the time is higher compared to the urban zone. In addition, the metals $\mathrm{Mg}$ and $\mathrm{Mn}$ occurrence in groundwater occurs naturally (CETESB, 2012).

From the wells investigated, 20 presented Fe concentrations above Brazilian regulations, according to Ministry of Health Ordinance 2914 of 2011 (BRASIL, 2011), where concentrations up to $0,30 \mathrm{mg} / \mathrm{L}$ are recommended for water for human consumption. The groundwater from the SGAIS naturally presents concentrations of Fe (CARASEK, et al., 2020), precisely because it is one of the main ions that make up the igneous rocks (CELLIGOI, 1999). In addition, in the 20 wells that presented changes, nine are located in the urban zone and 11 in the rural area. With this data, it was necessary to analyze statistically some relationship between the parameters analyzed in the laboratory and environmental data collected in the field and it was concluded that the wells present $\mathrm{Fe}$ in a natural way, but for five wells, it was observed structural problems of civil construction that allow direct surface water to enter. Therefore, the concentration of $\mathrm{Fe}$ in the soil of the study area has a high content.

Additionally, in the occurrence of long-term rainfall or high intensity, the bioavailable Fe in the soil is carried into the well, contributing to the increase concentration of the metal. Also, another factor to be considered is the presence of available oxygen from the surface waters influencing the process of chemical weathering, accelerating the processes of oxidation of the igneous rocks and releasing the Fe to the water, such processes may have influence for the metals $\mathrm{Mg}$ and $\mathrm{Mn}$.

According to the standard established by Ordinance 2914 of 2011 of the Ministry of Health (M.H) (BRASIL, 2011), the waters analyzed are presented with good quality and potable in the great majority.

In addition, according to Table 2, statistical analysis of groundwater analyzes for the study area (West Catarinense), the presence of fecal coliforms Escherichia Coli was positive for 11 wells, eight for urban and three for rural. For total coliforms, in the 100 analyzed wells, 47 presented contamination, which 27 were in the urban zone and 15 in the rural zone. Such wells are in disagreement with reference to the quality of water for human consumption, according to Administrative Rule 2914 of 2011 M.H.

Escherichia coli fecal coliform values ranged from 1,00 to 155.30 P.N/100 m/L for urban areas and 2,00 to 45,50 P.N/100 m/L for rural areas. Furthermore, the variation of total coliforms in urban and rural areas were from 1.00 to 2419.60 (maximum limit of accuracy according to the method employed). The concentration of the urban population contributes to the production of solid household waste, which affects water quality (CARASEK, et al., 2020). For the rest of the urban as well as the rural areas the most common form of disposal of domestic waste and sewage is through black cesspits, which are often undersized, affecting the area around them with contaminants saturating the soil and consequently infiltrating into areas saturated with groundwater, reaching more vulnerable wells according to the static level.

Although only 11 wells have presented Escherichia coli, this is a worrying result, because seven are community-based and the other four are private. Also, the main use is for human consumption, and none of them has a treatment system, or water is used in an in natural way. In the rural areas, only three wells have the presence of Escherichia coli, an alert for constant monitoring, since in the majority of the properties the agriculture prevails, with the confinement of poultry, swine, beef cattle and milk. In addition, all of these practices generate inputs such as animal waste, for which there is often no proper disposal or reuse in an adequate way, generating risk of contamination of soils, rivers, lakes and consequently groundwater.

Pathogenic microorganisms can survive in the soil for periods of days, months and even years because they have resistance forms in their life cycle that protect them from the adverse effects of the environment and can be carried along with the surface waters until reaching the saturated zones of groundwater reserves (SHARMA, 2005). 
Moreover, another fact that arouses great care with the groundwater of rural areas and the relationship with coliforms is the indiscriminate use of antimicrobials in confined animal production, which has triggered the increase of resistant microorganisms. These organisms can be transported to surface waters, fruits, vegetables, grains and dairy storage systems, which are then resold on the regional market. In the case of contamination of water resources by coliforms or other microorganisms, these can become potential contaminants on a large scale, without considering some types of virus that were not addressed in this research, and there are indications that they can percolate and reach the groundwater, explaining cases of hepatitis in people who consume water in the countryside (BERTONCINI, 2008).

Antimicrobial resistant strains of Escherichia coli have been observed in groundwater (MECKEL et al., 1995; GALLERT et al., 2005), rivers (WEBSTER et al., 2004) and sewage (REINTHALER et al., 2003). According to Nanni (2014) the occurrence of potential contamination of the SGAIS for the study area is high due to the economic and agro industrial profile, besides the population growth that accompanies the economic development of the region.

In this research, it was analyzed $\mathrm{NO}_{3}{ }^{-}$concentrations, with a positive result for all the 100 wells of the Serra Geral Aquifer, that have a higher concentration for urban areas with an average of $3,06 \mathrm{mg} / \mathrm{L}$ and $1,56 \mathrm{mg} / \mathrm{L}$ for the zones rural areas. None of the samples exceeded the maximum limit allowed by Ministry of Health regulations, Ordinance 2914 of 2011, which human concentrations up to $10,00 \mathrm{mg} / \mathrm{L}$ are stipulated. The wells that presented high values, above $5,00 \mathrm{mg} / \mathrm{L}$, were found six in the rural zone and 12 in the urban zone, also 37 wells had concentrations above $3,00 \mathrm{mg} / \mathrm{L}$, which 28 were found in urban areas and nine in rural areas.

In urban areas, the $\mathrm{NO}^{-}$results show how altered the environment is. This result is explained by the urban problems, such as the excess of septic tank and the lack of sewage and treatment system, as well as problems of leaks and undersize of the systems. Treatment of residential and industrial sewage, where the release of water with high nutrient load is discharged in natural environments saturating rivers and soils. This causes contamination of surface waters, as the contamination will infiltrate underground without adequate mechanical and chemical natural filtration, reaching groundwater. Another factor is the high $\mathrm{NO}_{3}$ solubility and the low retention in the soil, directly collaborating to increase the concentration in groundwater.

The wells that presented $\mathrm{NO}^{-}$above $5,00 \mathrm{mg} / \mathrm{L}$ in the rural space are related to the small distance of rearing animals and agents of risk of contamination, which the largest one is 50 meters. Confined animal production in the region is very important to the economy, this segment generates inputs such as wastes that are discarded and reused in an inadequate manner in most cases.

Another exacerbate factor is the lack of riverain zones and the use of nitrogen fertilizers in the crops, because when applied to the soil the excess can be leached and consequently reach areas of infiltration and recharge of aquifers as well as streams and rivers in the surroundings. Thus, when there is no riparian vegetation and vegetation cover in the vicinity of planting areas, this becomes an aggravating factor for the increase of the nitrogen compounds concentration in the groundwater, due to the fact that the plant roots do not occur, besides facilitating the leaching of the excess in the soil, infiltrating along with the water due to the high mobility mainly of $\mathrm{NO}^{-}$( $\mathrm{JU}$ et al, 2006). Soil saturation by nitrogen compounds directly contributes to the increase of $\mathrm{NO}^{-}$in groundwater, since the natural filtration occurs through the soil and when saturated the filtration process becomes ineffective (CARASEK, et al., 2020).

In the study of the herbicide glyphosate, it was selected the main vulnerable wells of the research for possible contamination (wells located in plantations), which were selected 25 wells from the rural area for the analyzes, all of the SGAIS. Despite the method used, through high performance liquid chromatography, the quantity / detect glyphosate in the samples were not analyzed. In this method, the limit of detection and quantification was for the analyte's search as compared to Administrative Rule 2914 of the M.H, which the maximum tolerable is $500 \mu \mathrm{gL}-1$, but the occurrence of glyphosate in the samples concentrations were lower than the limit of detection. Another relevant fact is the half-life time in about 50 to 70 days of the agrochemical in water (SANCHís et al., 2011). Therefore, if the herbicide has been applied within 50 days, the risk of not being detected by the degradation of the molecule until the sample preparation and analysis process should not be neglected.

It was selected 25 urban zone wells for BTEX analyzes (monochromatic hydrocarbons - benzene, toluene, ethylbenzene, o-xylene, $\mathrm{m}$-xylene, $\mathrm{p}$-xylene). The selection of the wells was directed to sites

$\begin{array}{lllll}\text { Caminhos de Geografia } & \text { Uberlândia-MG } & \text { v. 21, n. } 77 & \text { Out/2020 } & \text { p. 59-70 }\end{array}$


with great potential for possible contamination by petroleum derivatives (BTEXs), then the wells inserted within areas where there are mechanics workshops and fuel stations, or near these areas.

In the 25 wells, no contamination was detected or quantified as positive because our calibration curve was developed in an extremely accurate way and with a sensitivity of up to $2 \mathrm{ppb}$.

Although the results do not show any traces of petroleum derivatives, it is emphasized that the monitoring of these areas is very important for future studies, aiming to analyze soil samples in the surroundings, since small leaks are usually retained in the soil and, consequently release vapors that may spread and be released into the atmosphere and into the occurrence of precipitation to surface water and groundwater.

In this research, it was included five wells of the GAS, a water reserve that is still under-exploited in the region due to the depth and difficulty of reaching the Botucatu Formation, besides the fact that the drilling value is high and often economically unviable for the agricultural sector and for human consumption. So, the GAIS information in the West of Santa Catarina still needs to be better studied and discussed. It can be noticed the difficulty of drilling wells in the GAIS in the city of Chapecó, because between the five wells known, only one is for collective use and for human consumption, and the others are for particular use in the promotion of agro industrial area.

Still in the GAIS, for the pH samples, the minimum was 6,45 , maximum of 9,25 and the general average of 8,45 . For $\mathrm{Cl}^{-}$the concentration in the samples was mild with a minimum of $1,10 \mathrm{mg} / \mathrm{L}$ and a maximum of $59,00 \mathrm{mg} / \mathrm{L}$ and a general average of $35,07 \mathrm{mg} / \mathrm{L}$. The minimum total alkalinity was 72,40 $\mathrm{mg} / \mathrm{L}$ and maximum of $176,20 \mathrm{mg} / \mathrm{L}$ with a general average of $131.80 \mathrm{mg} / \mathrm{L}$. It was also analyzed the concentration of $\mathrm{SO}_{4}{ }^{-2}$ in the samples, which presented concentrations of $<5,00 \mathrm{mg} / \mathrm{L}$, maximum of 134.70 and an overall mean of $113.63 \mathrm{mg} / \mathrm{L}$. In addition, the ion $\mathrm{Na}^{+}$was found in the samples and presented a minimum of $0.70 \mathrm{mg} / \mathrm{L}$ and a maximum of $176.00 \mathrm{mg} / \mathrm{L}$.

Figure 3 - pH, Total Alkalinity and chloride ratio in GAIS waters.

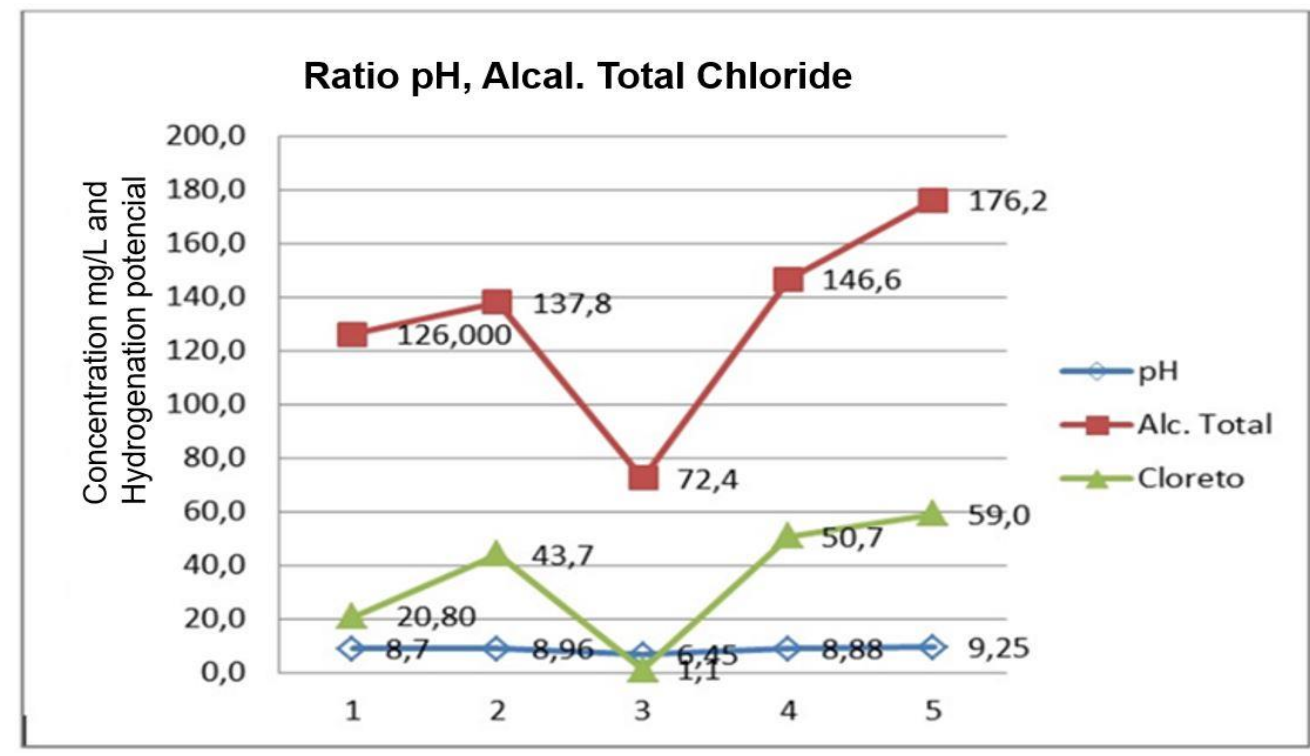

Source - Authors, 2019.

The results show that the water refers to the confined aquifer because the $\mathrm{pH}$ of the GAIS shows an increase in relation to the depth of the top of the aquifer. It is observed that as the $\mathrm{pH}$ increases, total alkalinity and chlorides raises exponentially. The presence of $\mathrm{Cl}$ - refers to minerals such as halite $(\mathrm{NaCl})$ and silvite $(\mathrm{KCl})$ that have high solubility and may be responsible for the release of this anion in the deep waters of GAIS (FREEZE et al., 1979).

Furthermore, in the case of the $\mathrm{SO}_{4}^{-2}$ ion, several minerals may be responsible for the release occurring by dissolution. The minerals gypsum $\left(\mathrm{CaSO}_{4} .2 \mathrm{H}_{2} \mathrm{O}\right)$ and anhydrite $\left(\mathrm{CaSO}_{4}\right)$ are the most common of the sulfated minerals. However, because they generally occur in small amounts in the 
GAIS, a longer time and depth of percolation is required for $\mathrm{SO}_{4}^{-2}$ to become the predominant anion (HISCOCK; BENSE, 2014; CETESB, 2001; SILVA, 1983).

In addition, the presence of the ion $\mathrm{Na}^{+}$is related to the abundance of this alkali metal in the environment and its high solubility in water, then the process of infiltration of the waters from the ground to the percolation by the formation of the aquifers enriches and increases the concentration of this salt, besides the wide distribution in the mineral sources (CUSTÓDIO, 1976).

The results for Escherichia coli fecal coliforms and total samples from the five wells of the GAIS showed negative values, as well as other microorganisms, in compliance with Administrative Rule 2914 of the M.H. These results were expected because the GAIS has a physical barrier that contributes to the mechanical and chemical filtration of the waters due to the overlapping of the Serra Geral formation, besides the study area, the confinement of the waters of the GAIS is proven.

The importance of the SGAIS/GAIS study detailed in the western region of Santa Catarina is political and environmental, since currently the great exploitation of groundwater in the region occurs in a disorderly way, where SGAIS is the main source of supply (SCHEIBE, HIRATA, 2008). Without understanding, the system groundwater will continue to be exploited without proper attention and responsibility for the protection to the future of the generations.

\section{CONCLUSION}

Through microbiological and physicochemical indicators, it was possible to verify that, the SGAIS aquifer meets the criteria and functions of social, economic and environmental use. Water in this territory is a resource and the exploitation of aquifers is cheaper than the recovery of surface water.

Another issue that needs to be added is the unconcern with the unproductive and abandoned wells found in fieldwork, because they are direct sources of groundwater pollution.

In general, the water quality of the GAIS in the study area is satisfactory for the collective human use.

The results found in this study point to the need for further studies in the State of Santa Catarina and in every State that address the integrated and shared management of water resources in the basins or hydrographic regions established in that territory.

It was also noticed that there is no concern on the part of well owners to clean, protect and maintain them constantly. In addition, cleaning, maintenance and prevention of wells could occur at least every four years, which it is possible to observe oxidation and infiltration problems. In conclusion, there is a need for mitigation measures with extreme urgency in this regard.

\section{REFERENCES}

APHA (American Public Health Association). Standard Methods for Examination of water and wastewater. 20. ed. Washignton D. C., 1998.

BALDISSERA, Adriana Diniz.; REIS, Almir Francisco. A cidade e as águas - Chapecó e a microbacia do lajeado São José. In: Anais III Seminário Nacional sobre o Tratamento de Áreas de Preservação Permanente em Meio urbano e Restrições Ambientais ao Parcelamento do Solo. APP Urbana 2014. UFPA - Belém, 10 a 13 de setembro de 2014. 16 p. Disponível em: http://anpur.org.br/app-urbana2014/anais/ARQUIVOS/GT5-160-23-20140516222259.pdf. Acesso em 10-09-2018.

BAVARESCO, Paulo Ricardo. Colonização do Extremo Oeste Catarinense: contribuições para a história campesina da América Latina. In: VII Congresso Latino Americano de Sociologia Rural - La cuestión rural en América Latina: Exclusión y Resistência Social, 2006, Quito - Equador. La Cuestión rural en América Latina: Exclusión y resistência social, 2006. v. 01.

BERTONCINI, E. I. Tratamento de efluentes e reuso da água no meio agrícola. In: Revista Tecnologia \& Inovação Agropecuária. São Paulo- SP, junho de 2008. 
BITTENCOURT, A.V.L et al. Influência dos basaltos e de misturas com águas de aquíferos sotopostos nas águas subterrâneas do Sistema Aquífero Serra Geral na Bacia do Rio Piquiri, Paraná - BR. Rev. Águas Subterrâneas, n. 17, p.67-75, 2003. https://doi.org/10.14295/ras.v17i1.1313

BRASIL. Ministério da Saúde. Portaria no 2.914, de 12 de dezembro de 2011. Dispõe sobre os procedimentos de controle e de vigilância da qualidade da água para consumo humano e seu padrão de potabilidade. Brasília, DF, 2011.

CARASEK, F. L.; BALDISSERA, R.; VLADIMIR OLIVEIRA, J.; SCHEIBE, L. F.; DAL MAGRO, J. Quality of the groundwater of the Serra Geral Aquifer System of Santa Catarina west region, Brazil. $\begin{array}{llllll}\text { Groundwater for Sustainable Development. v. } 10 . & \text { e-100346, }\end{array}$ https://doi.org/10.1016/j.gsd.2020.100346

CELLIGOI, A. Considerações sobre análises químicas de águas subterrâneas. Geografia, Londrina, v. 8, n. 1, p. 91-97, jan/jun. 1999.

CETESB. (Companhia Ambiental do Estado de São Paulo) (São Paulo). Qualidade das águas subterrâneas 2013-2015 no Estado de São Paulo. São Paulo: CETESB, 2012. B - - (Série Relatórios / CETESB, ISSN 0103-4103). Disponível http://cetesb.sp.gov.br/aguas-subterraneas/wpcontent/uploads/sites/13/2013/11/Cetesb QualidadeAguasSubterraneas2015 Web 20-07.pdf.

Acesso 12-07-2019.

CETESB. (Companhia Ambiental do Estado de São Paulo). Água subterrânea e poços tubulares. São Paulo: CETESB, 2001. 481 p. CPRM, Serviço Geológico do Brasil.

CUSTÓDIO, E.; \& Llamas, M. R. Hidrologia Subterrânea. Barcelona, Omega, t.1, 1976.

CUSTODIO, E., DA SILVA Jr., G. Basic concepts on the environmental role of groundwater and the effects of its development [Conceptos básicos sobre o papel ambiental das águas subterrâneas e os efeitos da sua explotação]. Bol. Geol. Min. v.119, p. 93-106, 2008.

DAL PISSOL, A.; SOUZA-FRANCO, G. M. 2003. Avaliação da qualidade das águas através de macroinvertebrados bentônicos em corpos de água no município de Maravilha (SC). Acta Ambiental Catarinense, vol. 2, no. 2, p. 7-21.

FACCO, Janete. Os conflitos ambientais no processo de urbanização na bacia hidrográfica de abastecimento de água de Chapecó-SC. Dissertação de Mestrado em Ciências Ambientais (Unochapecó) - Chapecó (SC): 2011, 231 f.

FACCO, Janete; ENGLER, Júlie Monique. O processo histórico de urbanização de Chapecó (19502016) - Notas sobre: a ocupação urbana, os planos diretores e os conflitos ambientais. P. 287- 324. Chapecó em Foco: textos e contextos sobre o espaço urbano regional. (e-book). NASCIMENTO, Ederson; VILLELA, Ana L. V. (Orgs). São Carlos: Pedro \& Paulo, 2017. 597p. ISBN: 978-85-7993388-2.

FACCO, Janete; FUJITA, Camila; BERTO James L. Agroindustrialização e Urbanização de ChapecóSC (1950 - 2010): uma visão sobre os impactos e conflitos urbanos e ambientais. Santa Cruz do Sul: REDES - Rev. Des. Regional, v. 19, n. 1, p. 187 - 215, jan/abr 2014.

FAPEU, Fundação de Amparo a Pesquisa e Extensão Universitária. PROJETO REDE GUARANI/SERRA GERAL. Coordenador Técnico do Projeto Prof. Dr. Luiz Fernando Scheibe. Florianópolis, 2015. Disponível em: https://rgsgsc.wordpress.com/metas/. Acesso 10-09-2018.

FILIPINI, Gedalva T. R. Os recursos hídricos na Bacia do Rio Jacutinga, Meio-Oeste de SC: o uso da terra e a qualidade das águas. Tese (Doutorado) - Universidade Federal de Santa Catarina, Centro de Filosofia e Ciências Humanas, Programa de Pós-Graduação em Geografia, Florianópolis -SC, 2013. Disponível https://repositorio.ufsc.br/xmlui/handle/123456789/122753. Acesso 13-10-2018. 

Manuela Gazzoni dos Passos

FREEZE, Allan R.; CHERRY, John A.; et al. Águas subterrâneas. Tradução: Everton de Oliveira (Coord.). São Paulo (SP): 2017. ISBN 978-85-94189-00-4.

FUNCEME. Fundação Cearense de Metereologia e Recursos Hídricos. Governo do Ceará. Software QualiGraf. Fortaleza, CE, 2015. Disponível http://www3.funceme.br/qualigraf/. Acesso 20-10-2017.

GALLERT, C.; FUND, K.; WINTER, J. 2005. Antibiotic resistance of bacteria in raw and biologically treated sewage and in groundwater below leaking sewers. Applied Microbiology and Biotechnology, 69: 106-112. https://doi.org/10.1007/s00253-005-0033-7

HISCOCK, KEVIN M.; BENSE, Victor F. Hydrogeology: Principles and practice. 2. ed. Oxford: Wiley Blackwell, 2014. 545 p.

$\mathrm{JU}$, X.T. et al. Nitrogen balance and groundwater nitrate contamination: Comparison among three intensive cropping systems on the North China Plain. Environmental Pollution. n. 43, v. 1, p. 117-125, sep. 2006. https://doi.org/10.1016/j.envpol.2005.11.005

MECKEL, D. M.; CALABRESE, J. P.; BISSONNETTE, G. K. 1995. Antibiotic resistant gram-negative bacteria in rural groundwater supplies. Water Research, 29 (8): 1902-1908. https://doi.org/10.1016/0043-1354(95)00013-B

NANNI, A. S. Tipos de Aquíferos: aquíferos em Santa Catarina. Notas de aula da disciplina de Hidrogeologia. - UFSC: Florianópolis, 2014.

REGINATO, P.A. R.; AHLERT, S.; GILIOLI, K. C.; CEMIN, G. Caracterização hidrogeológica e hidroquímica do aquífero livre do manto de alteração da Formação Serra Geral, na bacia hidrográfica Taquari-Antas, região nordeste do estado do Rio Grande do Sul. Ambi-Agua, Taubaté, v. 7, n. 2, p. 143-162, 2012. (http://dx.doi.org/10.4136/ambi-agua.903).

REBOUÇAS, Aldo, da C. Águas subterrâneas. In: Águas doces no Brasil: Capital Ecológico, uso e conservação. (Org.) BRAGA, Benedito; TUNDISI; José G.; TUNDISI, Takako M.; CIMINELLI, Virgínia S. T. - 4ª Ed., São Paulo: Escrituras Editora, 2015.

REINTHALER, F. F. et al. 2003. Antibiotic resistance of Escherichia coli in sewage and sludge. Water Research, 37: 685-1690. https://doi.org/10.1016/S0043-1354(02)00569-9

SANCHÍS, J.; KANTIANI, L.; LLORCA, M.; RUBIO, F.; GINEBREDA, A.; FRAILE, J.; GARRIDO, T.; FARRÉ, M. Determination of glyphosate in groundwater samples using an ultrasensitive immunoassay and confirmation by on-line solid-phase extraction followed by liquid chromatography coupled to tandem mass spectrometry. Anal. Bioanal Chem. 2011. https://doi.org/10.1007/s00216-011-5541-y

SANTA CATARINA. Lei oㅜ 14.675 de abril de 2009. Código Estadual de Meio Ambiente. Florianópolis, 2009.

SANTOS, A.C. Notions of Hydrochemistry. In: FEITOSA, F. A. C.; MANOEL, J.F. Hydrogeology: Concepts and Applications. Fortaleza: CPRM, LABHID-UFPE, 1997. 412 p.

SCHEIBE, L.F.; HIRATA, Ricardo C. A. Contexto tectônico dos Sistemas Aquíferos Guarani e Serra Geral em Santa Catarina: uma revisão. Águas Subterrâneas. São Paulo, Brasil. ABAS, 2008. p. 1 14. e-ISSN 2179-9784 (eletrônico). Disponível em: https://aguassubterraneas.abas.org/asubterraneas/article/view/23794 Acesso 25-06-2019.

SILVA, R.B.G. Estudo Hidroquímico e Isotópico das Águas Subterrâneas do Aquífero Botucatu no Estado de São Paulo. Tese de Doutorado. IGC/USP. 1983. 133 p.

SILVA, D. D.; da MIGLIORINI, R. B.; SILVA, E. de C.; LIMA, Z. M.; de MOURA, I. B. Falta de saneamento básico e as águas subterrâneas em aquífero freático: região do Bairro Pedra Noventa, Cuiabá (MT). Eng. Sanitária Ambient. v. 19, p. 43-52, 2014. https://doi.org/10.1590/S1413$\underline{41522014000100005}$

$\begin{array}{llllll}\text { Caminhos de Geografia } & \text { Uberlândia-MG } & \text { v. } 21, \text { n. } 77 & \text { Out/2020 } & \text { p. } 59-70 & \text { Página } 69\end{array}$


SHARMA, P.D. Environmental Microbiology. Alpha Science International Ltd. Harrow, UK. 2005.

TRINDADE, Larissa de Lima. Gestão Integrada de Recursos hídricos: papel, potencialidades e limitações dos Comitês de Bacias Hidrográficas. Tese (Doutorado) Programa de Pós-Graduação Interdisciplinar em Ciências Humanas da Universidade Federal de Santa Catarina. Florianópolis-SC, 2016.

WEBSTER, L. F. et al. 2004. Identification of sources of Escherichia coli in South Carolina estuaries using antibiotic resistance analysis. Journal of Experimental Marine Biology and Ecology, 298: 179195. https://doi.org/10.1016/S0022-0981(03)00358-7

Recebido em: 14/11/2019

Aceito para publicação em: 03/07/2020 